\title{
Afet Kriz Yönetiminde Sosyal Medyanın İşlevselliği ve Zararları Üzerine Bir İnceleme
}

\author{
Kader DEMIRÖZ ${ }^{1}$
}

\section{Öz}

Geçmişten günümüze afetler dünya üzerinde sıkça yaşanan ve yarattığı kayıp ve zararlar nedeniyle en çok korkulan olaylardan biridir. Son yıllarda afet yönetimi alanında yapılan çalışmalar, afet risklerini azaltmaya ve afet nedeniyle oluşan kriz ortamını yönetmeye yönelik yeni yaklaşımlar getirmiştir. Özellikle teknolojinin ve internetin günlük hayatımızın ayrılmaz bir parçası haline gelmesi ile birlikte afet yönetimi ve afet kaynaklı kriz yönetiminde yeni yöntemler geliştirilmektedir. Sosyal medya afet yönetimi ve afet kaynaklı krizlerin yönetiminde ise son yıllarda önemli bir rol oynamaktadır. Fakat yine sosyal medyanın kötü kullanııması durumunda kriz yaratabilecek durumların ortaya çıkabileceği unutulmamalıdır. Yapılan bu çalışma literatürdeki bilgiler ışığında, sosyal medyanın afetlerin farklı safhalarındaki etkilerinin yanında, kriz ve afet oluşturma potansiyeline değinerek; sosyal medyanın afet, afet yönetimi ve afet kaynaklı kriz yönetimine etkileri ve bu konulardaki işlevselliği üzerine bilgi veren bir araştırmadır. Bir derleme türü olan bu araştırmada, afet yönetiminde henüz çok fazla değinilmemiş bir konu olan sosyal medya ve afet yönetimi ilişkisi üzerine yapılacak olan yeni çalışmalar için yararlı bir kaynak olması hedeflenmektedir.

Anahtar Kelimeler: Afet, Afet Yönetimi, Sosyal Medya, Kriz Yönetimi.

\section{A Research on the Functionality and Damage of Social Media in Disaster Crisis Management}

\begin{abstract}
Disasters from the past to the present day is one of the most frequently experienced events in the World and the most feared due to losses and damages it creates. In recent years, studies in disaster management have brought new approaches to mitigate disaster risks and manage the crisis environment caused by disaster. Especially with the fact that technology and internet became an integral part of our daily lives, new methods are developed for disaster management and disaster-related crisis management. Social media has played an important role in the management of disaster and disaster-related crisis in the recent years. However, it should be kept in mind that if social media is misused, there may be situation that may create a crisis. In this study, in the light of the information in the literature, in addition to the effects of crisis and disaster formation; The research provides information on the effects of social media on disaster, disaster management and disaster-related crisis managementand its functionality in this areas. This research, a form of compilation, aims to be a useful resource for new work on social media and disaster management, which is not yet addressed in disaster management.
\end{abstract}

Keywords: Disaster, Disaster Management, Social Media, Crisis Management.

\footnotetext{
${ }^{1}$ Dokuzeylül Üniversitesi, Sosyal Bilimler Enstitüsü, Afet Yönetimi Anabilim Dalı, Afet Yönetimi Programı İmir

* Ilgili yazar / Corresponding author: kaderdemroz@gmail.com

Gönderim Tarihi / Submission Date: 11.05.2020

Kabul Tarihi / Acception Date: 29.11.2020
} 


\section{GíRiş}

Afetler geçmişten günümüze yaşanmakta olan, yarattığı zarar ve kayıplar nedeniyle insanlar ve canlılar üzerinde olumsuz sonuçlar doğuran olaylar olarak bilinmekte. Hem Dünya hem de Türkiye' de meydana gelen afetler sonucu maddi ve manevi kayıplar oluşmakta, ülkelerin ekonomileri sarsılmaktadır. Yıllar boyunca insanlar doğanın veya insanın neden olduğu bu felaketlerin etkilerini en aza indirmeye çalışmış ve kimi ülkeler bunu başarmıştır.

Düşünen, üreten, gelişen insanoğlu tarih boyunca duygularını düşüncelerini, edindiği bilgi ve tecrübeleri aktarmak amacıyla birçok yola başvurmuştur. Bunu en ilkel haliyle duvarlara yapılan resimler daha sonrasında dilin ve yazının kullanılması ile sözlü, yazılı iletişim teknikleri; teknolojinin gelişmesi ve elektronik aletlerin kullanımı ile yeni iletişim teknikleri izlemiştir. Teknolojinin geldiği son nokta ile bilginin ve haberlerin saniyeler içinde erişildiği ve internet aracılığı ile kullanılan, sosyal medya platformlarının kullanılması iletişim ve haberleşme amacı ile kullanılan en yaygın araçlardan biri olarak kabul görmektedir. Durum böyle iken günün her saatinde kullandığımız bu platform çoğu zaman bilginin erişilme kolaylığı açısından baktığımızda oldukça kullanışı görünmektedir. Fakat yanlış kullanım durumlarında topluluklar için kaotik bir ortam yaratarak çeşitli zararlara neden olmaktadır. Diğer bir deyişle yanlış kullanılan bu platform afetten sonra olumsuz sonuçlar doğuracak niteliğe sahip olabilmektedir.

Bu çalışmanın temel amacı sosyal medya kullanımının afetler üzerindeki etkisinin olumlu ve olumsuz yanlarına değinerek çözüm önerileri sunmaktır. Bu amaçla öncelikle sosyal medya, afet, afet yönetimi, kriz yönetimi kavramları, sosyal medyanın afet ve kriz oluşturma potansiyeli Türkiye ve dünya örnekleri, sosyal medyanın afet ve kriz yönetiminde etkili ve etkileşimli kullanılması durumunda yararları incelenmiş ve bu konularda çözüm önerileri sunulmuştur.

\section{SOSYAL MEDYA, AFET YÖNETIMI VE AFET KRIZ YÖNETiMi KAVRAMLARI}

Saitoğlu' nun (2018:64) yaptığı tanıma göre sosyal medya; “...kişilerin sınırları belli olan bir sistem şeması içerisinde açık veya yarı açık şekilde kendilerine ait profil oluşturmalarına izin veren, farklı kişilerle birtakım özel materyalleri paylaşmasını sağlayan ve bu kişilerin listesini ve onların bağlantılı olduğu diğer kişilerin listesini gösteren, anlık olarak yazılı veya görüntülü olarak iletişim kurmalarına imkan veren dijital tabanlı ortamlardır".

IFRC'nin tanımına göre afet; "topluluğun veya toplumun işleyişini ciddi bir şekilde bozan ve topluluğun veya toplumun kendi kaynaklarını kullanarak başa çıkma yeteneğini aşan can kaybı, ekonomik kayıplar veya çevresel kayıplara neden olan ani ve felaket getiren olaydır. Afetler insan ve doğa kaynaklı olabilmektedir".(IFRC, 2020) Afet yönetimi ise afet sürecinin tanımlanması, planlanması ve yönetilmesi (Karaman, 2017: 2) olarak tanımlanabilmektedir.

Kriz örgüt ve insanların yaşamlarında karşılaştıkları karmaşıklık durumudur (Demirtaş, 2000:353). Aniden ya da yavaşça gelişebilen bir değişiklik olmakla birlikte, ciddi sorunlara neden olduğundan dolayı ivedilikle müdahale edilmesi gereken durumlardır (Yazar, 2008:14). Krizin literatür de çeşitli tanımları mevcuttur ve afet kaynaklı krizler insanları panik ve endişeye sürüklemektedir. Oluşabilecek kriz durumlarına karşı alınacak önlemler, krizin oluşması durumunda zarar azaltma faaliyetleri, krizden sonra krize maruz kalan kesimin yeniden yapılanması için gerekli olan tüm hazırlıkların yapılması, faaliyetlerin uygulanması ve kontrol edilmesi kriz yönetimi olarak tanımlanmaktadır (Büyükkaracığan, 2016: 201). Kriz iletişiminin iyi bir şekilde yürütülmesi aynı zamanda krizin iyi yönetilmesini sağlamaktadır(Afetlerde Sosyal Medya Kullanımı: 
Van Depremi Örneği, ty: 2). Bu durum ise organizasyonlara karşı öfke ve düşmanlığı azaltan bir unsurduryapılması ile birlikte krizorganizasyona karşı öfke ve düşmanlığı azaltan bir unsurdur (Afetlerde Sosyal Medya Kullanımı: Van Depremi Örneği, ty: 2). Dolayısıyla oluşabilecek diğer krizlerde vatandaşın organizasyona güvenmesinin yanında yönetimi kolaylaştıran bir unsur haline gelmektedir. Bu durum afet sonrası krizler için de söz konusudur. Afet sonrası oluşan kriz ortamlarının doğru yönetilmemesi krizin kötü sonuçlar doğurmasına neden olabilmektedir. Bu nedenle afet yönetimi safhasında krizlerin doğru yönetilmesi toplumun yöneticilere ve personele olan güvenini artırması ile birlikte afet yönetimi faaliyetlerine katılımı sağlayabilmektedir.

Medya bilgiyi birey ve topluluklara ileten, eğitim ve bilgi aktarımı gibi sorumluluğu olan görsel, işitsel araçların tümü (Soydan ve Alparslan, 2014: 55) olarak tanımlanmakla birlikte özellikle afet ve kriz yönetiminde önemli bir rol üstlenmektedir. Teknolojinin gelişmesi ile birlikte geleneksel medya olarak tabir edilen medya araç gereçlerinin (görsel, işitsel ve basılı medya araç gereçleri) yerini yeni medya araç gereçleri (sosyal medya) almıştır. Geleneksel medyada halkın yayın içeriğinde herhangi bir değişiklik yapamaması ve iletişimin tek yönlü olmasından (Baranseli, 2012: 2) dolayı halkın etkileşimde bulunduğu, içerikler hakkında yorum yapabildiği medya türü olan sosyal medya kullanımı da son yıllarda artmıştır. Ayrıca bu platformların rahat kullanımı ve hızlı erişilebilirliği de bu nedenler arasında sayılabilir.

Aşağıdaki grafiklerde Dünya ve Türkiye'deki nüfus bilgilerine ve sosyal medya kullanımına ilişkin veriler bulunmaktadır. Dünya üzerindeki nüfus 2015-2019 yılları arasında arttı̆̆ı görülmektedir. Fakat sosyal medya kullanan nüfusun oranındaki artış dünya nüfus oranındaki artışa oranla daha fazladır. Bu durum her yıl dünya üzerinde sosyal medya kullanımının önceki yıllara göre artan oranda seyrettiğini göstermektedir.

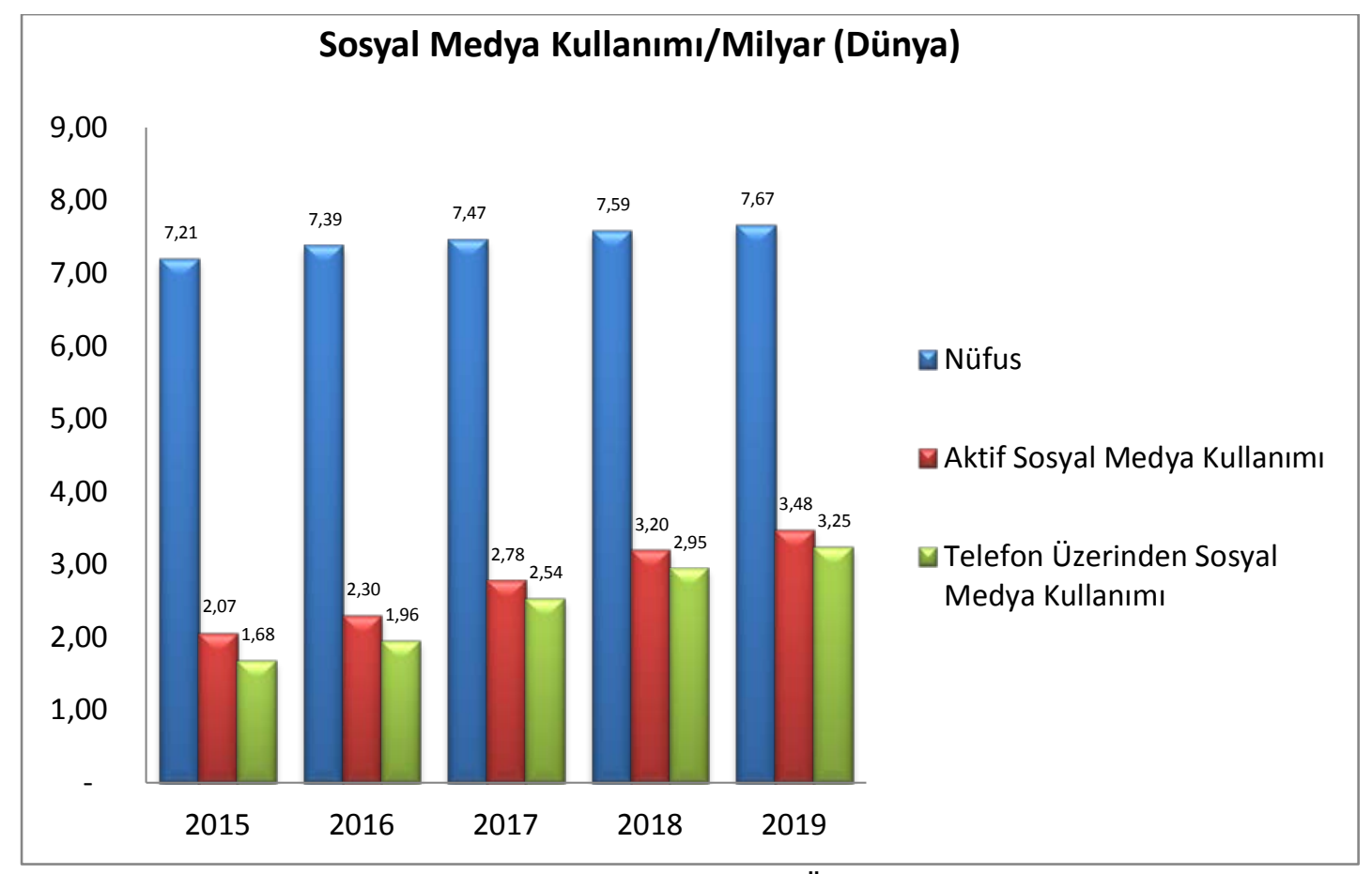

Grafik 1: Sosyal Medyanın Dünya Üzerinde Kullanımı

(We Are Social Global Digital Yearbooks/2015-2019: 2020) 
Bu durum Türkiye için de benzer şekilde seyretmektedir. 2015-2019 yılları arasında sosyal medya kullanımı her yıl artan oranda devam etmektedir. Dolayısıyla hem internet hem sosyal medya kullanımında nüfus artışına ve internete erişimin kolaylaşmasına bağlı olarak sosyal medya kullanımında artış beklenebilir.

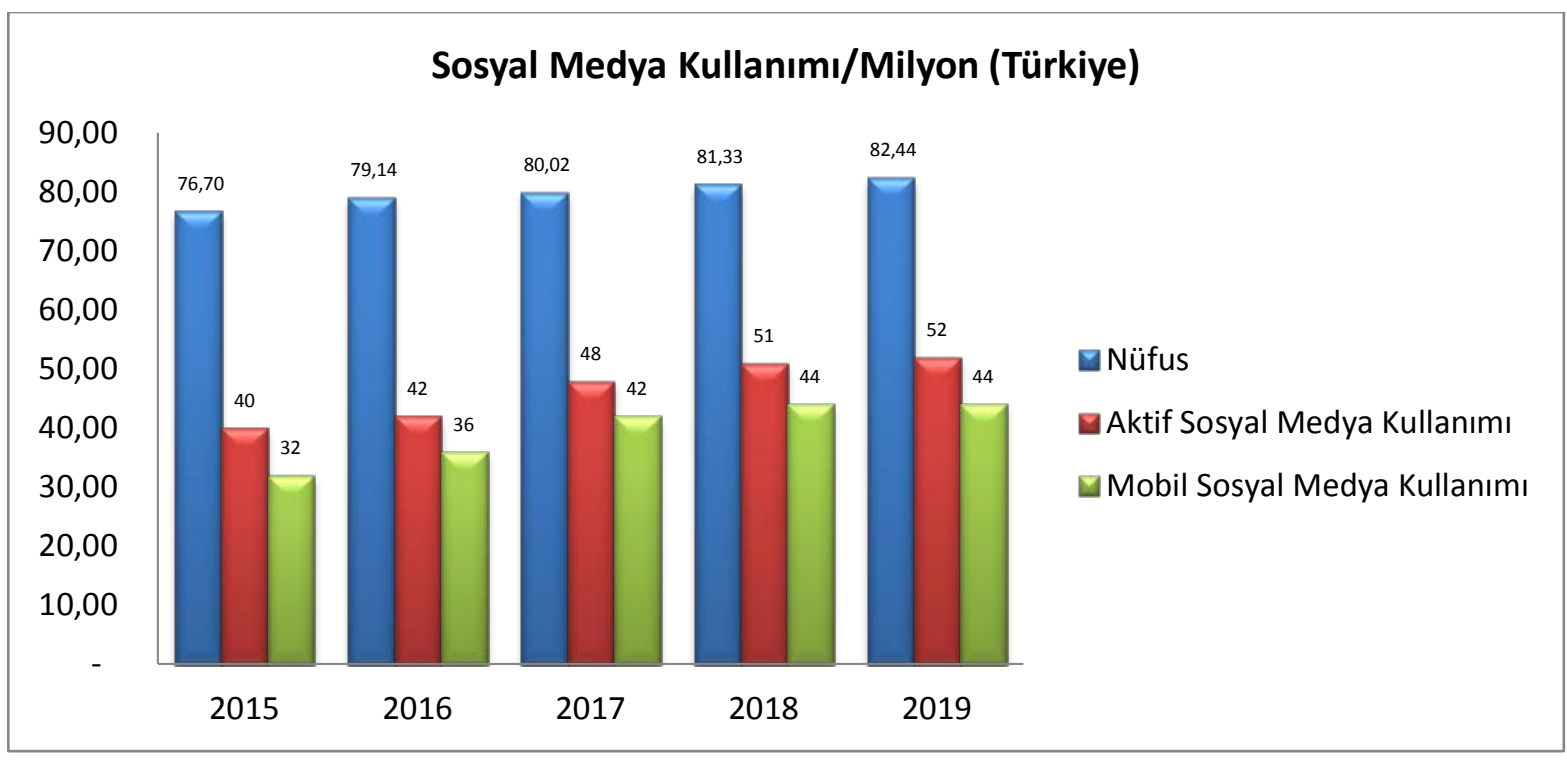

Grafik 2: Sosyal Medya Türkiye Kullanımı

(We Are Social Turkey Digital Yearbooks/ 2015-2019: 2020)

Dünya ve Türkiye'de internet ve sosyal medya kullanımı artan oranda devam etmesi bireylerin günlerinin azımsanmayacak kadar önemli kısmını internet ve medyayla birlikte geçirmesine neden olmaktadır. Türkiye'de insanlar internet kullanımı için günlük ortalama 7 saat 15 dakika harcamakta olup bu sürenin ortalama 2 saat 46 dakikası sosyal medya için ayrılan süredir (We Are Social/ Turkey-2019: 2020).

$\mathrm{Bu}$ denli fazla kullanılan platformların afet ve afet kriz yönetimi açısından etkili, etkin ve amaca uygun bir şekilde kullanılması durumunda geniş kitlelere oldukça hızlı bir şekilde erişim sağlanarak hedef kitleye - afetzede, halk - istenilen her türlü bilgi gönderilebilir ve hedef kitle de intiyaç durumlarında sorumlu kişi ve kurumlarla - kamu kurum kuruluşları, STK'lar- iletişime geçebilir.

\section{SOSYAL MEDYANIN AFET VE KRIZ OLUŞTURMA POTANSIYELI TÜRKIYE VE DÜNYA ÖRNEKLERI}

İnsanoğlu tarih boyunca birçok medya aracını kullanmıştır. Teknolojinin son yıllarda hızlı bir şekilde gelişmesi ile birlikte bireyler hayatlarını hızlı bir şekilde yaşamaya başlamıştır. Bu durum bilgiye kısa sürede ulaşılmasını gerektirmektedir. Dolayısıyla sosyal medya bilgiye kolay ulaşı Imasını ve birey ve kurumlar arasındaki etkileşimi artıran bir mecra olarak tanımlanabilir. İletişim, bilgi ve medya paylaşımı, etkileşim kurmak gibi çeşitli amaçları olan sosyal medya dünya üzerinde birçok olayın hızlıca yayılmasında ve kitlelerin örgütlenmesinde rol oynamaktadır. Bu durumun Türkiye ve Dünya'da çeşitli örnekleri bulunmaktadır. Sosyal medyanın, olayların hızlıca yayılması ve örgütlenmenin sağlanmasına yönelik etkileri arasında; Arap coğrafyasında başlayan Arap Baharı, Türkiye' de yapılan Gezi Parkı Eylemleri, Wikileaks Eylemleri, Amerika Birleşik Devletleri New York kentinde yapılan Wall Street Eylemleri ve Fransa'da başlayıp Avrupa'nın çeşitli ülkelerine yayılan Sarı Yelekliler gibi olaylar örnek olarak verilebilmektedir. Bu olaylar arasında şüphesiz en etkili olanı Arap Baharı' dır. Hükümetleri devirerek devrim niteliği kazanan Arap Baharı, 2010 
yılında 26 yaşındaki Tunuslu Muhammed Buazizi' nin bir pazar yerinde kendisini yakması ile başlamıştır (ïHH, 2020). Ortadoğu ve Kuzey Afrika'da baş gösteren eylemlerin, örgütlenme ve iletişim aracı olarak sosyal medya araçlarından yararlanılmasının ardından ( Babacan ve diğerleri, 2011: 66), sosyal medya' nın örgütlenme üzerine etkileri daha çok konuşulmaya başlanmıştır.

Sosyal medya tek başına Arap Baharı' nın asıl nedeni olmasa da isyanın saman alevi gibi büyümesine neden olmuştur (Halıcı, 2020). Büyük bir coğrafyaya yayılan bu olay Tunuslu Muhammed Buazizi' nin geçim sıkıntıları nedeniyle kendini yakması sonucu başlamıştır. Olay sosyal medya ağları yardımıyla hızlı bir şekilde yayılmış ve daha sonra hükümet karşıtı eylemlerle devam etmiştir. Kimi Arap ülkeleri domino etkisi gibi yayılan bu olay sonucu çareyi internetin fişini çekmede arasalar da başarılı olamamışlardır (Rosa, 2020). Arap Baharı sonucu başta Tunus, Mısır, Libya olmak üzere ülkelerdeki rejimler değişmiş ve diktatörler koltuklarını bırakmak zorunda kalmışlardır ( Çelik, 2015: 39). Ayrıca Suriye gibi ülkelerde rejim değişikliği olmasa bile iç karışıklıklardan ve daha sonrasında yaşanan terör olaylarından (Aras, 2014: 12) dolayı başta Türkiye olmak üzere çevre ülkeleri etkileyen göç dalgaları yaşanmıştır (Çelik, 2015: 46). Arap Baharı her ne kadar siyasi bir olay olarak değerlendirilse de geniş bir coğrafyada fiziksel, ekonomik ve sosyal kayıplar doğurmasından ve akabinde yıllar süren savaşları ve göç dalgalarını getirmesinden dolayı aynı zamanda insan kaynaklı bir afet olarak nitelendirilebilir. Literatürdeki tanımlara bakıldığında insan kaynaklı afetler insan faktörünün rol oynadığı savaş, çatışma, terör, göçler, kazalar gibi olaylar olarak tanımlanmaktadır (AFAD, "Afet Terimleri Sözlüğü”, 2020) . İnsan faktörünün fazlaca etkili olduğu bu hareketin savaş, terör, göç gibi sonuçları ortaya çıkmakla birlikte çevre ülkeleri ekonomik, sosyal, siyasal, fiziksel kayıplara neden olmuştur. Bu nedenle sosyal medya aslında insan kaynaklı bir afetin oluşmasındaki asıl faktör olmasa bile hızlı bir şekilde yayılmasına aracılık etmiştir. Bu yönü ile baktığımızda sosyal medya hibrit savaş olarak tabir edilen savaşların ve saldırıların bir bileşeni olarak tanımlanabilir ${ }^{2}$.

Sosyal medyanın örgütlenmedeki gücünün kanıtlandığı bir başka olay ise Türkiye'de 2013 yılında başlayan Gezi Parkı Eylemleridir. Halk bu eylemler başladığı andan itibaren Facebook ve Twitter üzerinden paylaştıkları gönderiler ve düzenledikleri örgütlenme faaliyetleri ile birlikte sokaklara dökülmüştür (Topbaş ve Işık, 2014: 219). Gezi Parkı Eylemleri her ne kadar bir afet olarak nitelendirilmese de kargaşaya, kayıplara ve krizlere neden olduğundan dolayı acil durum olarak değerlendirilebilir.

Sosyal medyanın günümüzde yaygın bir şekilde kullanılması ile bu mecralarda ağızdan ağıza yayılım oluşmaya başlamıştır dolayısıyla kaynağının doğru olup olmamasına bakılmaksızın bilgiler hızlıca çok geniş kitlelere yayılmaya başlamıştır. Bu artan ivmeyle yayılması nedeniyle kişi, kurum ve kuruluşlar açısından bir "sosyal medya krizine" dönüşebilmektedir (Özdemir, 2017: 8).

Nitekim sosyal medya afet, afet sonrası oluşabilecek krizlerin ve acil durumların asıl nedeni olmamakla birlikte hızlı bir şekilde bilgi akışını, yalan haberlerin yayılmasını sağladığından dolayı provokasyonlara açık bir ortamdır. Dolayısıyla sosyal medyanın özellikle afet ve acil durumlarda dikkatli kullanılması gerekmektedir.

\footnotetext{
${ }^{2}$ Hibrit Savaş (Hybrid Attack): Klasik savaş, sivil, asker, organize şiddet, terör, suç ve savaş kavramları arasında kesin bir ayrımın olmadığı, şiddet kullanımının aynı zamanda devlet dışı aktörlerde görülebildiği çok boyutlu bir savaş türüdür (Bkz. Yusuf, Özer. (2018), "Savaşın Değişen Karakteri: Teori Ve Uygulamada Hibrit Savaş", Güvenlik Bilimleri Dergisi, 7(1), 29-56.)
} 


\section{SOSYAL MEDYANIN AFET VE KRIZ YÖNETIMINDE IŞLEVSELLIĞi VE ETKILEŞIMLI KULLANIMI}

Sosyal medya şüphesiz iletişimi ve bilgi akışını sağlayan bir platformdur. Özellikle afet ve kriz durumlarında insanlar daha fazla iletişim kurmaya çalışılar. Bunun nedeni insanların afet sonrası yakınlarının güvende olduklarını bilmek istemelerinden kaynaklanmaktadır, bunun yanında afet ve afetler sonrası kriz durumlarında olaya ilişkin güvenilir bilgileri almak isterler. Özellikle son yıllarda insanların iletişim için en çok tercih ettiği araçların başında da yine internet ve buna bağlı olarak sosyal medya gelmektedir.

Sosyal medya afet öncesi bilinçlendirme çalışmalarının yanında, afet sırasında bilgiye ulaşmak için kullanılabilecek hızlı bir yoldur. Bu süreç içerisinde sosyal medya araçlarının yanlış kullanılması ile kriz durumlarının ortaya çıkabileceği de unutulmamalıdır. Bu durumun yaşanmaması için afet sonrası bilgilendirmeyi yapacak olan kişiler, verilmesi gereken bilgileri soğukkanlı vermeli, güvenilir kaynaklara dayandırmalı ve net ve doğru bir şekilde açıklamalıdır (Çetinkaya, 2013: 331). Afet sonrası kriz durumunda bilgilendirmeler olabildiğince sık yapılmalı ve halk afetin durumundan haberdar edilmelidir böylelikle söylentiler ve dedikodular engellenerek durumun ikincil bir krize dönüşmesi engellenecektir. Bu durum halkın güveninin kazanılmasına ve sürecin daha iyi yönetilmesine yardımcı olur.

Sosyal medya ve kriz yönetimi ilişkisi ile ilgili çalışmalar henüz yeni yapılmaya başlanmıştır. Dolayısıyla bu konuda çalışmalar sınırlıdır fakat sosyal medyada meydana gelen kriz geleneksel krizle benzerdir. Bu nedenle sosyal medyanın kriz yönetimi klasik kriz yönetimi ilkelerine bağlıdır. Fakat bu anlayışın sosyal medya için tekrar gözden geçirilmesi gerekmektedir ( Diyadin ve Özdil, 2017: 408).

2011 yılında Amerika Birleşik Devletleri'nde 5.8 büyüklüğünde olan bir deprem sonucu afete müdahale eden personel halk ile Twitter üzerinden iletişime geçerek bölgedeki afet zararları ile ilgili bilgi vermiş ve halkın ne yapması gerektiğini bu yolla iletmiştir. Aksaklıklar nedeniyle cep telefonu konuşmasının yapılamadığı bu depremde halk yakınlarına ulaşmak ve kamu kurumlarından bilgi almak amacıyla Twitter ve kısa mesaj hizmetini kullanmıştır (Soydan ve Alparslan, 2014: 64).

Ülkemizde ise bu duruma örnek olarak 23 Ekim 2011 tarihinde olan Van Depremi'ni verebiliriz. Van depremi sosyal medya kullanıcılarının olabildiğince hızlı örgütlenerek yardım ve destek kampanyaları düzenlemesi ve hatta bazı bölgelerde enkaz altında yaralıların bulunduğuna dair gelen mesajlar ile arama kurtarma faaliyetlerine destek verilmesi aslında doğru kullanım çerçevesinde sosyal medyanın ne denli önemli olduğunu göstermektedir. Bu şekilde etkin ve etkili kullanılabilecek platformların kriz yönetiminde de yardımcı olabileceği durumu göz önünde bulundurulmalıdır.

Google ise "Kişi Bulucu" uygulaması ile Haiti ve Japonya depreminde insanların yakınlarına ulaşmasını sağlamıştır. Van depreminin akabinde bu hizmet Türkçe olarak kullanılmış ve sonrasında "online kriz yönetimi" sayfası eklenerek arama kurtarma faaliyetlerine de katkıda bulunmuştur (Özarslan, 2012: 231).

Yine bir sosyal medya platformu olan Facebook uygulamasının afet ve acil durumlar için kullanıma açtığı Güvenlik Durumu Kontrolü 2017 yılında gerçekleşen Ayvacık Depremi sırasında devreye girerek bölgede bulunan kişilerin kendi durumlarını yakınlarıyla paylaşmasını ve bölgede yakınları bulunan kişilerinde yakınlarının durumları hakkında bilgi sahibi olmasını sağlamıştır. 
Bir sosyal paylaşım platformu olan Facebook acil durumlarda yerel yönetimlere yardımcı olabilmek adına "acil durum uyarısı" özelliğini de geçtiğimiz aylarda ABD' de devreye sokmuştur. Şirketin yerel yönetimlere sunduğu bu hizmet yerel yönetimlere ait sayfalarda gönderilerin "acil durum uyarısı" olarak işaretlenmesinin ardından bölgede etkilenen kişilere durum ile ilgili mesaj gönderilmesi sağlanmaktadır. Şu ana kadar Amerika Birleşik Devletlerinde 350 yerel yönetim tarafından test edilmiş olan bu sistemin ilerleyen zamanlarda tüm dünyaya yayılması planlanmaktadır (Hürriyet, 2020). Afet, acil durum ve krizlere yönelik bu gibi uygulamaların, olayların gerçekleştiği bölgede bulunan insanların gerekli önlemleri almasını sağlayarak zarar ve kayıpların azalmasına yardımcı olabilecektir.

Bunun yanında Aralık 2019'da Çin'in Wuhan kentinde ortaya çıkan ve dünyanın büyük bir kısmına yayılan korona virüs salgınına ilişkin olarak sosyal medya üzerinden hastalığa ilişkin çeşitli kurumlar tarafından hastalıktan korunmaya yönelik paylaşımlar yapılmıştır (NTV, 2020). Korona virüs salgınına yönelik yapılan uyarı ve bilgilendirme paylaşımları gerek Türkiye gerekse dünya üzerinde büyük ilgi görmüştür. Hastalığın başlamasından 13.03.2020 tarihine kadar geçen süre zarfında sosyal medya kullanıcıları tarafından dünya genelinde salgına ilişkin olarak 275 milyonun üzerinde paylaşım yapılmıştır (NTV, 2020). COVID-19 Pandemisi an itibari ile küresel bir afet niteliği taşımaktadır bu süreçte en geniş kitlelere en hızlı şekilde duyuru ve bilgi paylaşımı şüphesiz medya araç gereçleri yoluyla yapılmaktadır ki günümüzde en çok kullanılan medya aracı ise sosyal medyadır. Bu yolla gönderiler hızlı bir şekilde yayılarak büyük kitlelere ulaşır.

Türkiye'de COVID-19 vakalarının görüldüğü günden itibaren Sağlık Bakanı Sayın Fahrettin Koca'nın tüm medya araçlarını kullanarak hastalığa ve önlemlere ilişkin yaptığı açıklamalar şüphesiz ki halkın gözünde süreci yöneten kişinin vatandaşı önemsediğini göstermekte ve vatandaşın güvenini artırmaktadır. Nitekim güvenin artması ise yönetimi ve iknayı kolaylaştıran unsurlardan biridir (Karaman, 2019:189) dolayısıyla sürecin yönetilmesini olumlu yönde etkileyebilir.

\section{SOSYAL MEDYANIN AFET VE KRIZ DURUMLARINDA YANLIŞ KULLANIMI VE ZARARLARI}

Sosyal medyanın afetler sonrası yanlış kullanımı da söz konusudur. Örneğin Türkiye'de 24 Ocak 2020 tarihinde Elazığ'da meydana gelen 6.8 büyüklüğünde (BBC, 2020) deprem sonucu arama kurtarma faaliyetlerinin devam ettiği sıralarda Twitter üzerinden enkaz altında kaldığını bildiren tweetler atılmış fakat hesap sahiplerinin aslında enkaz altında olmadığı anlaşıımıştır (Cumhuriyet Haber, 2020). Bunun yanında yine Elazığ'da bir döküm fabrikasının afetzedeler için battaniye, çorba, ekmek, çay dağıtımının yanında muayene ve barınma hizmetinde bulunacağına dair paylaşımlarda bulunulmuştur, fakat bu paylaşımlardan sonra fabrikanın aslında böyle bir açıklama yapmadığı fabrika tarafından belirtilmiştir (Keskin,2020). Sosyal medya üzerinden bu tarz paylaşım yapan bireylerin ve onları bu tarz davranışlarda bulunmaya yönelten faktörlerin üzerinde durulması gereken sosyolojik ve psikolojik açıdan araştırıması gereken bir konu olmakla birlikte, afete maruz kalan birey ve çalışan personel bu gibi paylaşımlardan zarar görebilmektedir. 


\section{Enkaz altındayım durumum iyi ama sesim duyulmuyor heralde telefon çekmiyor \#malatya \#elaziğ

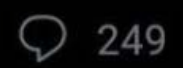

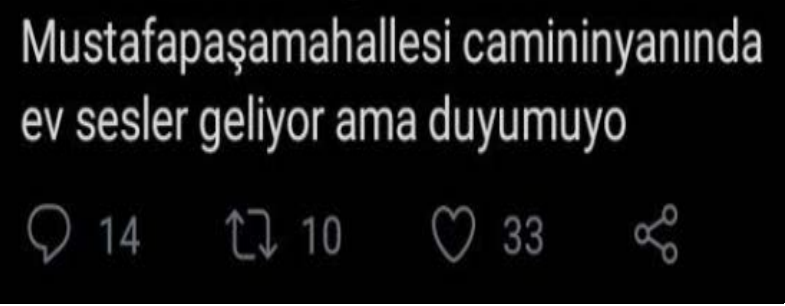

Fotoğraf 1: Bir sosyal medya hesabından hesap sahibinin enkaz altında olunduğuna dair yapılan paylaşım (Twitter, 2020).

\section{Pütürge afad ekipleri tarafından çıkarıldım hastanede sağlık kontrolündeyim. telefon çekmiyordu çaresizce beklerken herkese yazdım tweet bile attım. Hastanede telefonu açtım açınca tweetim paylaşılmış. Bildirimleri görünce şok oldum duyarlı insanlar iyiki varsınız \\ 02:21 25 Oca 20 saatinde $\cdot$ Twitter for iPhone}

Fotoğraf 2,3: Başka bir sosyal medya hesabından hesap sahibinin enkaz altında olduğuna dair yapılan paylaşım (Twitter, 2020).

Bahsi geçen konularda kişilerin yanlış bilgilendirmesi sonucu bu durumdan en çok zarar gören kişiler şüphesiz afetzedelerdir. İnsanların en çok desteğe ihtiyaç duyduğu durumlarda yanlış bilgilendirme ile yanlış yönlendirmenin yapılması arama kurtarma, yardım faaliyetlerinin aksaması ve afetten zaten zarar gören insanların yardım için şehir merkezinden kilometrelerce uzakta olan bir yere gitmesine neden olmuştur. Dolayısıyla bu olaylar hem afetzede hem de bölgede çalışan personel için fiziksel ve psikolojik bir yük olmuştur.

Bilinçsizce paylaşılan gönderiler, afetzede ve halkta gerginlik, huzursuzluk yaratabilmektedir. Bunun yanında afet sonrası sosyal medyada yayılan dedikodular provakasyonlar ile birlikte afet sırasında ikincil krizlere neden olabilmektedir. Aynı zamanda sosyal medya üzerinden yardımların kontrollü bir şekilde ilgili kurum ve kuruluşlarla koordineli olarak toplanması ve dağıtılması gerekmektedir.

Özellikle afetler sonrası çekilen trajik görüntüler - yaralı ve ölü insanların görüntüleri- diğer medya araçlarında sansürlenmektedir fakat sosyal medyada bu görüntüler apaçık paylaşılmakta ve yayılmaktadır dolayısıyla hem toplumun ruh sağlığını hem de görüntülerdeki kişilerin varsa yakınlarının ruh sağlığını olumsuz yönde etkilemesi ve özellikle yakınlarında travma oluşturması söz konusudur. Bu nedenle söz konusu içeriklerin paylaşılmasına ve yayılmasına neden olmamak amacıyla gerekli önlemler alınmalıdır. 


\section{SONUÇ}

Afetlerden sonra insanlar bölgede bulunan aile ve arkadaşlarına ulaşmaya çalışırlar. Bunun yanında beslenme barınma gibi intiyaçları karşılamak amacıyla yardım talebinde bulunmak için normal yaşamdan daha fazla iletişim trafiği olmaktadır. Sosyal medya yardım isteme ve bilgi paylaşımını ve afetlerle ilgili bilgilerin yayılmasını sağlar. Sosyal ağların yaygın kullanımı, afetzedelerin intiyaç duydukları kaynaklara hızlıca bağlantı kurmasına yardım eder (Velev ve Zleveta, 2012: 41).

Afetler günlük yaşantıdan farklı olarak kaos ortamı yarattıkları için kişilerin/kurumların/yönetimin doğru ve etkili bir şekilde iletişim kurması gerekmektedir. Çünkü bu gibi durumlarda insanlar daha gergin olmakta ve yapılan açıklamaların da yeteri kadar net, tatminkâr ve doğru olmaması provokasyonlara ve ikincil kaotik ortamlara neden olmaktadır.

Sosyal medya afet durumlarında faaliyetlere katılan kuruluşların tümünün iletişimini ve hızlıca faaliyete geçmesi için avantaj sağlar. Bu nedenle afetlerde görev alan kurum ve kuruluşların sosyal medyaya yönelik kriz planları -afet odaklı- olmalıdır (Karakulakoğlu, 2015: 281-282).

$\mathrm{Bu}$ nedenle sosyal medya üzerinden düzenlenen afete yönelik faaliyetlerin kurum/kuruluşlar/yetkili kişilerin ve sosyal medyadaki kullanıcılar ile işbirliği ve koordinasyon içinde gerçekleştirmesi ile sosyal medyanın afet ve kriz yönetiminde aktif /yararlı kullanımı söz konusudur.

Sosyal medya her ne kadar kriz ve afet durumlarının ana nedeni olmasa da olaya ilişkin görüntü ve paylaşımların hızlı bir şekilde yayılmasına neden olduğu için, olayların hızlı bir şekilde büyümesine ve grupların hızlı bir şekilde örgütlenmesine neden olabilmektedir.

Sosyal medya üzerinden yayılan her bilginin doğru olmama durumu söz konusudur. Bu nedenle doğruluğu kanıtlanmamış bilgilerin yayılması gerginliklere provokasyonlara neden olmaktadır. Bu durum ise var olan kriz ortamının daha da şiddetlenmesine neden olabilmektedir.

Elazığ Depremi'nden de tecrübe edindiğimiz üzere afetzedelere yönelik yardımlara ilişkin yapılan asılsız paylaşımlar afetzedelerin yanlış yönlendirilmesine neden olmaktadır. Afet nedeniyle gergin ve yorgun olan afet mağdurlarının bu gibi paylaşımlarla yanlış yönlendirilmesi onlara yüklenmiş ek bir yüktür. Yapılan yanlış paylaşımlar aynı zamanda afet personelinin işlerini aksatmakta ve hem afetzede hem de personel etkilenmekte olup, afet gibi kaynak yetersizliğinin olduğu durumlarda kaynakların yanlış yönlendirilmesine ve kaynak sarfiyatına neden olması söz konusudur.

Dünya'da ve Türkiye'de birçok afetten sonra yaralı ve/ veya ölen kişilerin felaket anına ilişkin görüntülerinin sosyal medya üzerinden sansürsüz bir şekilde yayılması söz konusudur. Bunun en yakın örneklerinden biri yine Elazığ depreminde can veren bir babanın çocuklarını korumak için onlara sarılması ve enkaz altında bu şekilde bulunmasıyla ilgili görüntülerin sosyal medyada paylaşılmasıdır. Bu durum her ne kadar diğer medya araçlarında sansürlenerek gösterilse de sosyal medyada bu ve bunun gibi görüntülerin sansürsüz ve sürekli erişilebilir olmasının felaketzede ve halkta olumsuz etkiler oluşturabileceği göz önünde bulunulmalıdır. 
Genel hatları ile afet yönetiminde sosyal medyanın etkili ve bilinçli kullanılması için;

- Bireyler, sosyal medyanın afet yönetimi safhalarında kullanımına yönelik bilgilendirilmeli ve bilinçlendirilmeli

- Yanlış ve art niyetli kullanımlara yönelik caydırıcı önlemler alınmalı. Bu şekilde kullanımın zararları hakkında bilgiler sosyal medya platformlarında yetkili kurumlarca sosyal medya platformları desteği ile verilmeli

- Sosyal medya platformlarında afet yönetimine yönelik çeşitli uygulamalar mevcuttur. Fakat bu uygulamaların bireyler ve yerel yönetimler tarafından ne derece etkili kullanıldığı ve bu uygulamalar hakkında bilgilerinin olup olmadığı tartışılabilir. Bu konu hakkında gerekli bilgilendirmeler yapılmalıdır.

Sonuç olarak sosyal medya etkili ve bilinçli kullanıldığı sürece afetlere yönelik bilgilendirme ve bilinçlendirme yapmak (kamu spotları vb.), acil durum iletişimini sağlamak, yetkili idare tarafından afetzedelere yönelik uyarıları yayınlamak, yardım faaliyetlerini koordine etmek gibi çeşitli faaliyetlerde büyük ölçüde yarar sağlayarak bilinçli ve dirençli toplumlar oluşmasını sağlar. Afete yönelik bilinç ve direnç ise kırılganlığı azaltarak afetlerin en az zararla atlatılmasını ve mümkün olan en kısa sürede toparlanmayı sağlar.

\section{KAYNAKLAR}

Aras, B., (2014). Arap baharı sonrası jeopolitik, iş̧iD ve Türkiye (Post-Arab spring geopolitics, ISIS and Turkey). Ortadoğu Analiz, 6(65), 10-13.

Babacan, M., Haşlak, İ., Hira, İ. (2011). Sosyal Medya ve Arap Baharı, Akademik Incelemeler Dergisi (AID), 6(2), 63-92.

Büyükkaraciğan, N. (2016). Türkiye'de Yerel Yönetimlerde Kriz ve Afet Yönetim Çalışmalarının Mevzuat Açısından Değerlendirilmesi, Selçuk Üniversitesi Sosyal ve Teknik Araştırmalar Dergisi, (12), 195-219.

Çelik, A. H. (2015). Buazizi'den Rabia'ya, Trablus' tan Şam'a Arap Baharının Sonuçları Üzerine Bir Değerlendirme. Akademik Yaklaşımlar Dergisi, 6(2), 34-53.

Çetinkaya, E., (2013). Afet Durumlarında Sağlık Kuruluşları İçin İletişimin Önemi ve Yönetimi, Kerim Hakan Altıntaş(Ed.), HAMER Acil ve Afet Durumlarında Sağlık Yönetimi, Ankara: Hacettepe Üniversitesi Yayınları, 329-333.

Demirtaş, H. (2000). Kriz Yönetimi. Kuram ve Uygulamada Eğitim Yönetimi. 23 (6), 353-373. Diyadin, A., \& Özdil, T., (2017). Krizlerle Baş Etmede Sosyal Medyanın Yeri ve Önemi, Ege Akademik Bakis, 17(3), 407-418.

Karakulakoğlu, S.,Doğal Afet ve Acil Durumların Yönetiminde Sosyal Medya Kullanımı: Twitter Örneği, Karakulakoğlu, S., Uğurlu, Ö. içinde, Iletişim Çalışmalarında Dijital Yaklaşımlar "Twitter", ss.281-294, Ankara: Heretik Yayınevi.

Karaman, Z.T.(2017). Afet Yönetimine Giriş Ve Türkiye'de Örgütlenme, Zerrin Toprak Karaman ve Asuman Altay(Ed.), Bütünleşik Afet Yönetimi, İzmir: Birleşik, 1-38.

Karaman, Z.T.(2019)Risk Toplumunda Afetlerde Erken Uyarı, Mukavemetli Toplum Ve Kamu Yönetiminin İkna Kapasitesi. Bitlis Eren Üniversitesi Sosyal Bilimler Enstitüsü Dergisi, 8(1), 185-212. 
Kriz Yönetimi, (2008). (Çev. Melis İnan), Harvard Business School Press Pocket Mentor, İstanbul: Optimist Yayınları.

Özarslan, Z., (2012), 23 Ekim 2011 Van Depremi Sonrasında Yaşanan Toplumsal Değişimde Yeni Medyanın Rolü, New Communication Technologies, 205-219.

Saitoğlu, C. (2018), Bir Haber Iletim Mecrası Olarak Sosyal Medya: 2015 Genel Seçim Sürecinde Yayınlanan Haberlerin Geleneksel Medya Ve Sosyal Medya Karşılaştırması, (Yayınlanmamış Yükseklisans Tezi), İstanbul Üniversitesi SBE Genel Gazetecilik Anabilim Dalı, İstanbul.

Soydan, E., \& Alpaslan, N. (2014). Medyanin Doğal Afetlerdeki İşlevi. İstanbul Journal of Social Sciences (2014) Summer, 7, 53-64.

Topbaş, H., \& Umur, I. Ş. I. K. (2014). Kurgu ile gerçeklik arasında gezi parkı eylemleri ve soysal medya. Birey ve Toplum Sosyal Bilimler Dergisi, 4(1), 197-230.

Velev, D., \& Zlateva, P. (2012). Use of social media in natural disaster management. Intl. Proc. of Economic Development and Research, 39, 41-45.

URL-1: AFAD, "Açıklamalı Afet Terimleri Sözlüğü/ İnsan Kaynaklı Afetler”, https://www.afad.gov.tr/aciklamali-afet-yonetimi-terimleri-sozlugu (Erişim Tarihi: 20.11.2020). URL-2: Afetlerde Sosyal Medya Kullanımı: Van Depremi Örneği, https://www.academia.edu/7055396/AFETLERDE SOSYAL MEDYA KULLANIMI VAN DE PREM\%C4\%B0 \%C3\%96RNE\%C4\%9E\%C4\%B0 Social Media Usage at Disasters CaS e Study of Van Earthquake, (Erișim Tarihi: 13.04.2020).

URL-3: Bağımsız İletişim Ağı, http://bianet.org/biamag/ifade-ozgurlugu/127684-arapdevrimindesosyal-medyanin-rol\%C3\%BC (Erişim Tarihi: 29.01.2020).

URL-4: Bağımsız İletişim Ağı, http://bianet.org/biamag/bianet/127597-devrimler-halasokaklarda-yapiliyor (Erişim Tarihi: 29.01.2020).

URL-5: BBC, "Elazığ depremi: 6,8 büyüklüğündeki sarsıntı can kaybı ve hasara yol açtı", https://www.bbc.com/turkce/haberler-turkiye-51244459 , (Erişim Tarihi: 13.04.2020).

URL-6: Cumhuriyet Haber, "Sahte Hesap Açıp ‘Enkaz Altındayım' Tweet'i Attılar” Http://Www.Cumhuriyet.Com.Tr/Haber/Turkiye/1716252/Sahte-Hesap-Acip-EnkazAltindayim--Tweeti-Attilar.Html, (Erişim Tarihi: 31.01.20).

URL-7: Baranseli, E., (2012), Geleneksel Medya ve Yeni Medya, http://dijitalkulturgra331.blogspot.com/2013/01/yeni-medya-ve-geleneksel-medyasunum.html?view=magazine , (Erişim Tarihi: 23.11.2019), s. 2.

URL-8: Hürriyet, "Facebook' ta 'Acil Durum' Dönemi Başlıyor”, https://www.hurriyet.com.tr/teknoloji/facebookta-acil-durum-donemi-basliyor-41315190, (Erişim Tarihi: 14.03.2020). URL-9: IFRC, "What is disaster", https://www.ifrc.org/en/what-we-do/disastermanagement/about-disasters/what-is-a-disaster (Erişim Tarihi: 30.09.2019).

URL-10: İH, “18 Aralık 2010 Arap Baharının Başlangıcı”, https://www.ihh.org.tr/haber/18aralik-2010-arap-baharinin-baslangici-1975 (Erişim Tarihi: 29.01.2020). 
URL-11: Özdemir, G., Iletişim Ve Sosyal Medya, 30 Ocak 2020 tarihinde Researchgate Sitesi: https://www.researchgate.net/publication/322571049 lletisim ve Sosyal Medya adresinden alındı.

URL-12: NTV, "Corona Virüs Sosyal Medyaya Nasıl Yansıdı ?"

https://www.ntv.com.tr/teknoloji/corona-virus-sosyal-medyaya-nasil-yansidi,Axgno1PBKUID8Le85byiw , (Erişim Tarihi: 14.03.2020).

URL-13: Teyit.org, Elazığ Depreminden Sonra Sığınılması Gereken Yerler İlgili İddialar, https://teyit.org/elazigda-deprem-sonrasi-siginilmasi-gereken-yerlerle-ilgili-iddialar/ (Erişim (Tarihi: 31.01.2020).

URL-14: We Are Social "2015 Digital Report", https://www.slideshare.net/wearesocialsg/digital-social-mobile-in-2015, (Erişim Tarihi: 02.02.2020).

URL-15: We Are Social "2016 Digital Report", https://www.slideshare.net/wearesocialsg/digital-in-2016, (Erişim Tarihi: 02.02.2020).

URL-16: We Are Social "2017 Digital Report", https://wearesocial.com/special-reports/digitalin-2017-global-overview, (Erişim Tarihi: 02.02.2020).

URL-17: We Are Social "2018 Digital Report", https://www.slideshare.net/wearesocial/digitalin-2018-global-overview-86860338, (Erişim Tarihi: 02.02.2020).

URL-18: We Are Social "2019 Digital Report", https://wearesocial.com/global-digital-report2019, (Erişim Tarihi: 02.02.2020).

URL-19: We Are Social, Digital Data Report 2019/ Turkey, https://www.slideshare.net/DataReportal/digital-2019-turkey-january-2019-v01/4, (Erișim Tarihi: 05.10.2019).

URL-20: We Are Social "Digital in 2018 in Western Asia" https://www.slideshare.net/wearesocial/digital-in-2018-in-western-asia-part-1-northwest86865983 , (Erişim Tarihi: 22.11.2020) 